\title{
Relationship of Work-life Balance and Work Place Performance of Employees in Sri Lanka
}

\author{
Article by Chaminda Deshapriya Malalasekara \\ Ph.D. in Management, Texila American University, Guyana \\ E-mail:Chaminmal@yahoo.com
}

\begin{abstract}
In the companies that the researcher has worked, something apparent was the fact that some employees were happy at work and also glad to be employed in their positions. On the contrary the researcher observed that some others weren't content in their places of work. It was also observed that those who were happy performed well and the others who weren't content lacked in their performance. This initiated the thinking of whether there is any relationship of work-life balance and work place performance. If employees underperform it would affect productivity and eventually the bottom-line of the organization in which they work. This led to the desire to conduct this research relationship of work-life balance and work place performance. Further, as the scope and extent of this research was so vast, it was conceptualized to limit the study to an accessible sample within the national boundaries of Sri Lanka hence the research title: "Relationship of Work-life Balance and Work Place Performance of Employees in Sri Lanka".

The researcher has conducted this research study by carrying out both quantitative and qualitative research amongst a wide cross section of the Public and Private Sector employees. Researcher has used 500 sample in major industries of Sri Lanka Amongst them office staff, field staff and employees of different levels was included. Different industries, such as agriculture, construction, health care, manufacturing and industrial institutions was considered as much as those in the public sector such as ministries, government departments, semi-government and government owned business undertakings.
\end{abstract}

\section{Introduction}

The topic of the thesis is broadly related to the areas of Work-life balance and its impact to the productivity, with special focus on Work -life balance it will increase employee happiness as well as productivity during the working hours. It is also closely connected with human psychology.

In the companies that the researcher has worked, something apparent was the fact that some employees were happy at work and also glad to be employed in their positions. On the contrary the researcher observed that some others weren't content in their places of work. It was also observed that those who were happy performed well and the others who weren't content lacked in their performance.

Today have unusual stress and this was observed as being due to pressure by the employers who ultimately strive to achieve higher productivity and a greater bottom-line, and this pressure cascades right down to the bottom of the employment pyramid. How does this affect their own happiness, health and above all their family life? It is a known fact that a person from an unhappy home is often likely to underperform in their places of work than those from a pleasant home.

The research attempts to find these influences so that this new knowledge will provide both employers and employees to achieve work-life balance and work place performance, in fact improve work place performance. Toffoletti and Starr (2016) asserts that work load decreases effectiveness of employees and that leads to unhappy employees. They in particular concerns about women's work-life balance and their work place performance and they believe that because of the unbalanced nature in a women's work life has created many conflicts in their personal lives.

From the researcher's own observations, it can be added that this is not exclusively for women but common to both genders in Sri Lanka. The researcher plans to conduct this research study by carrying out both quantitative and qualitative research amongst a wide cross section of the Public and Private Sector 
DOI: 10.21522/TIJMG.2015.SE.19.01.Art008

ISSN: 2520-310X

employees. Amongst them office staff, field staff and employees of different levels will be included. Different industries, such as agriculture, construction, health care, manufacturing and industrial institutions will be considered as much as those in the public sector such as ministries, government departments, semigovernment and government owned business undertakings.

\section{Objective of the study}

The goal of this study is to investigate the relationship between work-life balance and workplace performance, find out which causes of family life may affect to the workplace success or failures of employees, and how it is important to the organization.

- Investigation and determine causes for work place performance

- Find out the causes affect to increase work place satisfaction?

- Find out importance of Work-life balance for healthy life.

- To find out the importance of flexible working hours for work-life balance

- To find-out the relationship between work-life balance and work place performance

\section{Identification / Defining research problem}

The greatest challenge that organizations are confronting today is the poor productivity of employees during their working hours. Lack of commitment and inefficient working style affecting to the overall development of the society. The researcher observed many employees are unsatisfied with their job role due to heavy and restless workload, hence its leads to increase the number of stressful employees in both private and government sectors. It was also observed that employees who performed are enjoying their family life as well as personal-life. The researcher plans to conduct this research to understand the causes which make underperforming employees of both private and public sector in Sri Lanka.

\section{Research questions}

1. What is the influence of work life balance on performance of the employees in Sri Lanka?

2. What is the influence of work life balance on job satisfaction of the employees in Sri Lanka?

3. What is the influence of work load on performance of the employees in Sri Lanka?

4. What is the influence of long working hours on performance of the employees in Sri Lanka?

\section{Conceptual frame work}

This is an explanatory model and specifies the nature of hypotheses of the study, which were set out in diagrammatic form of figure 


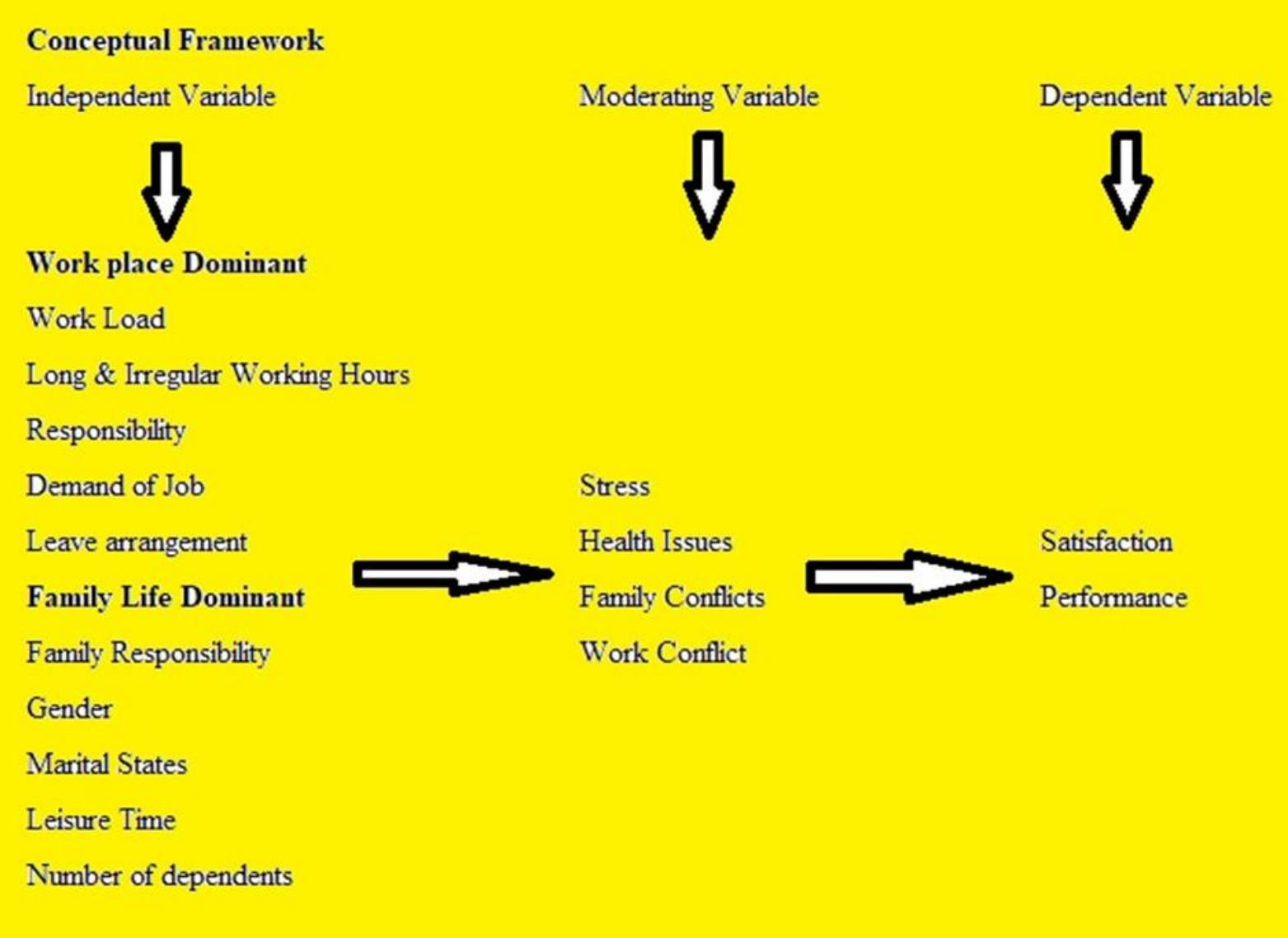

Figure 1. Conceptual frame work

\section{Hypothesis}

H0: It is hypothesized that Work-life balance and employee satisfaction will not be significantly related H1: It is hypothesized that Work-life balance and employee satisfaction will be significantly related H0: It is hypothesized that work-life balance increases, employee conflicts will not decrease $\mathrm{H} 2$ : It is hypothesized that work-life balance increases, employee conflicts will decrease H0: It is hypothesized work-life balance increases, health issues and stress will not decrease H3: It is hypothesized work-life balance increases, health issues and stress will decrease H0: It is hypothesized that Work-life balance and workplace performance will not be significantly related H4: It is hypothesized that Work-life balance and workplace performance will be significantly related

\section{Review of literature}

There is no any universally acceptable theory or definition of work-life balance. But universe has understood importance of this topic. Therefore, many research and articles can find about work life balance. The research has referred wide range of literatures for better research. This chapter explain and argue many aspects of Work- Life balance with the reference of past research and articles.

\section{Introduction}

Work life balance is the phenomenon of striking an ideal balance between the professional life of an individual and their personal life with all of their respective associations (Clark, 2000). The level of importance being given to this phenomenon these days is because of the harmful results brought about because of the severe lack of this phenomenon. According to the research paper, Is Happiness Relative? 
DOI: 10.21522/TIJMG.2015.SE.19.01.Art008

ISSN: 2520-310X

An effective work life balance makes a person happier and more content (Veenhoven, 1991). Coupled with the increase level of stress experienced by the majority of professionals in every field according to the latest studies (Beehr \& Newman, 1978), the need becomes evident there is a need to want to know what is the importance of integrating work life balance into our lives. Thus, it is widely accepted that considering maintaining work life balance in all of one's affairs is the current need of the hour.

\section{Work life balance}

\section{Theoretical definitions}

Work-life balance is a broad concept, defined in different ways by different researchers using diverse dimensions. Work life balance was initially termed as work family conflict, Kahn et al. (2008), defined as "a form of inter role conflict in which the role pressures from work and family domains are mutually incompatible in some respect. That is, participation in the work (family) role being made more difficult by virtue of participation in the family (work) role". Marks and Mac Dermid (1996) defined role balance as "the tendency to become fully engaged in the performance of every Role in one's total role system, to approach every typical role and role partner with an attitude of attentiveness and care. Put differently, it is the practice of that even-handed alertness known sometimes as mindfulness". In simple terms, work-life balance is defined as "the extent to which individuals are equally engaged in and equally satisfied with work and family roles". Kirchmeyer (2000) also defined a balanced life as achieving satisfying experiences in all life domains.

\section{Materials and methods}

\section{Research design}

The researcher was gathering secondary data from different industries to understand the performance level of employees during last five years. The sample was dividing to two phases according to their performance by investigation KPIs. Through the questionnaire researcher was investigate their family, personal life, health, working hours and workplace satisfaction.

\section{Target population}

GDP concern three major industries in Sri Lanka such as Service, Agriculture and industries. There are many sub industries under these three major sectors. The target population consisted of 10 sub industries which is cover all three major industries both government and privet sector in Sri Lanka.

\section{Sample and sampling technique}

\section{Sample size}

A sample is a portion or part of the population of interest. The 10 industries participated in the study with the population of employees in the both government and privet sector being 7,904,038 according to Sri Lanka labor force survey annual report (2016), from where a sample size was drawn.

Sample size of at least 385 people or more would be necessary. The research has done with 500 samples in selected industries.

\section{Data collection}

The researcher was plan to use interval scale which also known as likert scale for all variables in this study ranging from $1=$ 'Strongly dis agree' until to 5= 'Strongly agree'. The questionnaire was distributing among selected samples in various sectors. The researcher was planned to distribute questionnaire through human resource department of selected companies. Total 500 has responded for questionnaire out of 600 $(83 \%)$. 


\section{Statistical methods applied in analysis}

In order to subject the data to statistical testing, the collected data will be coded and analyses SPSS (Originally Statistical package for the Social Sciences) version 24 for Windows. The data will also be tabulated with frequency tables and percentages using MS- Excel.

\section{Results and discussion}

\section{Introduction}

Many organizations are highly concern about their productivity during the operation. But still they not concern about relationship of work- life balance and productivity. The ultimate objective of this research is find impact of WLB for productivity improvements. The chapter elaborate the method of data collected to achieve research objective through the conceptual frame work. This will describe the findings deeply and it will test the hypothesis which was given.

This chapter focuses on presenting the findings and discussions of the study by detailing the general characteristics of the study sample, descriptive study, the aggregates of the variables, the correlation analysis of the dependent and independent variables. The chapter details the research findings and discussions on the strength of the model; test of hypothesis and the summary. The chapter also presents analysis and findings of the study as set out in the research methodology. The study findings were presented showing influence of work life balance on performance in the both government and privet sector industries in Sri Lanka. The data was gathered exclusively from the semi-structured questionnaires as the research instrument. This instrument was designed in line with the objectives of the study. The results here were presented in frequency tables and discussions.

Subsequently empirical results of other statistical tools were discussed in the research with the purpose of testing hypotheses and demonstrate the relationship among key variable of the conceptual model.

\section{Work place dominant}

Table 1. Work place dominant

\begin{tabular}{|l|l|l|l|l|l|l|l|}
\hline Work place Dominant & SD & DA & N & A & SA & Mean & $\begin{array}{l}\text { St. } \\
\text { Devi. }\end{array}$ \\
\hline $\begin{array}{l}\text { Average actual hours work per } \\
\text { week }\end{array}$ & & & & & & & \\
\hline I never work on Poya days & 24.4 & 18.2 & 24.2 & 16.4 & 16.8 & 2.83 & 1.403 \\
\hline I'm doing overtime often & 21.8 & 11.6 & 22.8 & 18.2 & 25.6 & & \\
\hline $\begin{array}{l}\text { My work responsibility } \\
\text { reasonable and manageable }\end{array}$ & 4.8 & 7 & 25.4 & 26.4 & 36.4 & 3.83 & 1.141 \\
\hline $\begin{array}{l}\text { I can finish my day work during } \\
\text { working hours }\end{array}$ & 6.4 & 21.6 & 21.6 & 24 & 26.4 & 3.42 & 1.252 \\
\hline I can take leave comfortably & 11.6 & 16.6 & 25.6 & 25 & 21.2 & 3.28 & 1.267 \\
\hline $\begin{array}{l}\text { There are some people to manage } \\
\text { my work during my holidays }\end{array}$ & 22 & 17.8 & 29.6 & 18.2 & 12.4 & 2.81 & 1.305 \\
\hline $\begin{array}{l}\text { I have social value and respect due } \\
\text { to my job role and position }\end{array}$ & 5 & 4.2 & 11.8 & 30.8 & 48.2 & 4.13 & 1.097 \\
\hline
\end{tabular}

The results of the study on work place dominant indicate that $43.8 \%$ of the respondents agreed that they are doing overtime often and $33.4 \%$ are never doing overtime in their career. This supports the finding by Burke and Greenglass (1999), who posited that in term of job attitudes, employee reporting high levels of both work-life and life-work conflict tend to exhibit lower levels of job satisfaction and organizational 
DOI: 10.21522/TIJMG.2015.SE.19.01.Art008

ISSN: 2520-310X

commitment However $39.8 \%$ disagreed with the statement of There are some people to manage my work during my holidays but $50.5 \%$ are telling that they can manage their works during working hours.

\section{Family life dominant}

Table 2. Family life dominant

\begin{tabular}{|l|c|c|c|c|c|c|c|}
\hline Family Life Dominant & SD & DA & N & A & SA & Mean & St.Di \\
\hline $\begin{array}{l}\text { I have enough time to spend } \\
\text { with my family and friends }\end{array}$ & 9.4 & 18.6 & 32 & 25.4 & 14.6 & 3.17 & 1.172 \\
\hline $\begin{array}{l}\text { I'm going outing with my } \\
\text { family and friends often }\end{array}$ & 8.6 & 24.6 & 24.8 & 27.6 & 14.4 & 3.15 & 1.193 \\
\hline $\begin{array}{l}\text { I never do my office work at } \\
\text { home }\end{array}$ & 14 & 17.2 & 23.6 & 18.2 & 27 & 3.27 & 1.387 \\
\hline $\begin{array}{l}\text { I have enough time to attend } \\
\text { my family events }\end{array}$ & 6.2 & 20 & 31 & 27.4 & 15.4 & 3.26 & 1.129 \\
\hline & & & & & & & \\
\hline
\end{tabular}

Findings on family life dominant in table below indicate that $40 \%$ of respondents Agreed that they wished they would be spend time with family and friend, with $42 \%$ of respondents also agreeing that they are going outing with their family and friends. Quite a majority of respondents $45.2 \%$ agreed on the statement that they never do their office work at home. Finally, 42.8.5 respondents are agreed that they have time to attend family events. However, this figure showing agreed amount of respondents are not more than $50 \%$. Many are neutral in this question and one third of employees are not agreed with the above statements.

\section{Moderate variable}

Table 3. Moderate Variable

\begin{tabular}{|l|l|l|l|l|l|l|l|}
\hline Moderate Variable & SD & DA & N & A & SA & Mean & $\begin{array}{l}\text { St. } \\
\text { Devi. }\end{array}$ \\
\hline I never get stress due to my work & 10.6 & 24 & 29.2 & 20.6 & 15.6 & 3.07 & 1.222 \\
\hline I do not have chronic illness & 17.6 & 10 & 12 & 22.6 & 37.8 & 3.53 & 1.505 \\
\hline I have enough time to do exercise & 18.6 & 23.2 & 27.2 & 18.4 & 12.6 & 2.83 & 1.28 \\
\hline $\begin{array}{l}\text { I didn't get medicine during last } \\
\text { year }\end{array}$ & 21.6 & 24.8 & 22.2 & 16.2 & 15.2 & 2.79 & 1.358 \\
\hline $\begin{array}{l}\text { I never have conflict with my } \\
\text { family members due to my job } \\
\text { role }\end{array}$ & 12.2 & 17.6 & 22.2 & 22.2 & 25.8 & 3.32 & 1.34 \\
\hline
\end{tabular}

With the analysis of moderate variables $36.2 \%$ are agreed with the statement of "I never get stress due to my work" and 34.6\% are not agreed. However, $29.2 \%$ are not agreed or disagreed for the statement this is showing that one third of respondents are suffer with stress and one third are not suffer with stress. In the other statement of chronic illness $60.4 \%$ are agreed that they don't have chronic illness in their life. When it comes to the exercise $41.8 \%$ respondents are telling that they don't have enough time to do an exercise. However, an overwhelming majority, 58\% agreed that they have no conflict among family members due to job role or job stress. 


\section{Analysis of variables}

Table 4. Independent variable and moderate variable

\begin{tabular}{|c|c|c|c|c|}
\hline & $\begin{array}{l}\text { Never get } \\
\text { Stress }\end{array}$ & $\begin{array}{l}\text { No } \\
\text { chronic } \\
\text { illness }\end{array}$ & $\begin{array}{l}\text { No Family } \\
\text { conflict }\end{array}$ & $\begin{array}{l}\text { No Work } \\
\text { Conflict }\end{array}$ \\
\hline No work load & 0.757 & 0.651 & 0.084 & 0.777 \\
\hline working hours & & -211 & -319 & \\
\hline $\begin{array}{l}\text { Responsibility is } \\
\text { manageable }\end{array}$ & 0.707 & 0.637 & 0.854 & 0.739 \\
\hline High job demand & -41 & 0.155 & 0.299 & -31 \\
\hline $\begin{array}{l}\text { Flexible leave } \\
\text { policy }\end{array}$ & 0.737 & 0.74 & 0.67 & 0.669 \\
\hline $\begin{array}{l}\text { Family } \\
\text { Responsibility }\end{array}$ & 0.177 & 0.075 & 0.43 & 0.302 \\
\hline Gender & -49 & 0.018 & 0.081 & 0.075 \\
\hline Marital status & -153 & 0.036 & -318 & -73 \\
\hline leisure time & 0.552 & 0.532 & 0.655 & 0.56 \\
\hline
\end{tabular}

Pearson Correlation was used to analyze the strength of association between all variables in this research study. The result, the Coefficient of Correlation (r) is 0.757. Based on the decision rule, there is strong positive correlation between work load and stress. The significance level is 0.000 which is below $0.05(\mathrm{p}<$ 0.05). Based on the decision rule for significant level, we reject the null hypothesis. Therefore, we conclude that "There is a positive relationship between employee work load and level of stress"

This means that stress will be increase when increase the work load of employees. Further research will be discussed about relationship of stress level and satisfaction of employees, and also discussed level of performance of the employees.

The result, the Coefficient of Correlation ( $\mathrm{r}$ ) is 0.637. Based on the decision rule, there is strong positive correlation between work load and health issues. As the above significance level is 0.000 which is below 0.05 ( $\mathrm{p}<0.05$ ). Based on the decision rule for significant level, we reject the null hypothesis. Therefore, we conclude that "There is a positive relationship between employee work load and health issues

This means that health issues will be increase when increase the work load of employees. Further research will be discussed about relationship of stress level and satisfaction of employees, and also discussed level of performance of the employees.

The result showing weak positive correlation 0.084 in between work load and family conflict but it showing strong 0.777 coefficient and co relation in between work load and work place conflict.

Next independent variable which is workload indicated that $r=-0.211$ while $p=0.000$. The result shows that there was a negative significant and weak association between working hours and health issues. third moderate variable which is role conflict indicated that $r=-0.311$ while $p=0.000$. The result showed that there was a negative significant and weak association between working hours and family conflict.

With the result of 3rd independent variable all four moderate variables are showing strong positive correlation with work responsibility while $\mathrm{p}=0.000$ (Level of stress, $\mathrm{r}=0.707$, Health issues 0.637 , Family conflict 0.854 , and work conflict 0.757 ).

The result, the Coefficient of Correlation (r) is 0.737 . Based on the decision rule, there is strong positive correlation between leave policy and stress. The significance level is 0.000 which is below $0.05(\mathrm{p}<0.05)$. Based on the decision rule for significant level, we reject the null hypothesis. Therefore, we conclude that "There is a positive relationship between leave policy and level of stress". 
DOI: 10.21522/TIJMG.2015.SE.19.01.Art008

ISSN: 2520-310X

The result, the Coefficient of Correlation ( $r$ ) is 0.669 . Based on the decision rule, there is strong positive correlation between leave policy and work conflict. As the above significance level is 0.000 which is below 0.05 ( $\mathrm{p}<0.05)$. Based on the decision rule for significant level, we reject the null hypothesis. Therefore, we conclude that "There is a positive relationship between employee leave policy and work conflict.

The result showing weak positive correlation 0.084 in between leave policy and family conflict and again weak positive correlation showing in between leave policy and health issues.

Table 5. Moderate variable and dependent variable $(\mathrm{P}=0.000)$

\begin{tabular}{|l|l|l|}
\hline & Satisfaction & Performance \\
\hline Never get stress & $\mathrm{r}=0.801$ & $\mathrm{r}=0.808$ \\
\hline Don't have health issues & $\mathrm{r}=0.719$ & $\mathrm{r}=0.629$ \\
\hline Never family conflict & $\mathrm{r}=0.869$ & $\mathrm{r}=0.865$ \\
\hline never Work conflict & $\mathrm{r}=0.842$ & $\mathrm{r}=0.909$ \\
\hline
\end{tabular}

Pearson Correlation was used to analyze the strength of association between all variables in this research study. The result, the Coefficient of Correlation (r) is 0.801. Based on the decision rule, there is strong positive correlation between level of stress and satisfaction, at the same time result is showing $\mathrm{r}$ is 0.808 strong positive correlation in between level of stress and performances.

Further results are showing that high positive correlation in between health issues and satisfaction, correlation and co efficient is $r=0.719$. At the same time $r=0.629$ correlation is showing by health issues and performance.

Above mention results are showing that there is strong positive correlation in between family conflict, satisfaction and performances however it's showing again strong positive correlation in between work conflict, satisfaction and performances.

\section{Hypothesis testing}

H0: It is hypothesized that Work-life balance and employee satisfaction will not be significantly related H1: It is hypothesized that Work-life balance and employee satisfaction will be significantly related

Table 6. Hypothesis testing 1

\begin{tabular}{|l|l|l|l|}
\hline \multicolumn{2}{|c|}{} & $\begin{array}{l}\text { I'm } \\
\text { successfully } \\
\text { balance my } \\
\text { work and } \\
\text { family life }\end{array}$ & $\begin{array}{l}\text { I'm } \\
\text { satisfied } \\
\text { with my job } \\
\text { role }\end{array}$ \\
\hline \multirow{2}{*}{$\begin{array}{l}\text { I'm successfully balance } \\
\text { my work and family life }\end{array}$} & Pearson Correlation & 1 & .938 \\
\cline { 2 - 4 } & Sig. (2-tailed) & & .000 \\
\cline { 2 - 4 } & $\mathrm{N}$ & 500 & 500 \\
\hline \multirow{2}{*}{$\begin{array}{l}\text { I'm satisfied with my job } \\
\text { role }\end{array}$} & Pearson Correlation & .938 & 1 \\
\cline { 2 - 4 } & Sig. (2-tailed) & .000 & 500 \\
\cline { 2 - 4 } & $\mathrm{N}$ & 500 & 5 \\
\hline
\end{tabular}

Pearson Correlation was used to testing hypothesis in this research study. The result, the Coefficient of Correlation (r) is 0.938. Based on the decision rule, there is strong positive correlation between work life balance and workplace satisfaction. The significance level is 0.000 which is below $0.05(\mathrm{p}<0.05)$. Based on the decision rule for significant level, we reject the null hypothesis. Therefore, we conclude that "There is a strong positive relationship between work life balance and workplace satisfaction.

This means that work place satisfaction will be increase when increase the work -life balance of employees. Further research will be discussed about relationship of stress level and satisfaction of employees. 
H0: It is hypothesized that work-life balance increases, employee conflicts will not decrease $\mathrm{H} 2$ : It is hypothesized that work-life balance increases, employee conflicts will decrease

Table 7. Hypothesis testing 2

\begin{tabular}{|l|l|l|l|}
\hline \multicolumn{2}{|c|}{} & $\begin{array}{l}\text { I'm } \\
\text { successfully } \\
\text { balance my } \\
\text { work and } \\
\text { family life }\end{array}$ & $\begin{array}{l}\text { I don't have } \\
\text { conflict with } \\
\text { my work }\end{array}$ \\
\hline \multirow{2}{*}{$\begin{array}{l}\text { I'm successfully balance } \\
\text { my work and family life }\end{array}$} & Pearson Correlation & 1 & .828 \\
\cline { 2 - 4 } & Sig. (2-tailed) & & .000 \\
\cline { 2 - 4 } & $\mathrm{N}$ & 500 & 500 \\
\hline \multirow{2}{*}{$\begin{array}{l}\text { I don't have conflict with } \\
\text { my work }\end{array}$} & Pearson Correlation & .828 & 1 \\
\cline { 2 - 4 } & Sig. (2-tailed) & .000 & 500 \\
\cline { 2 - 4 } & $\mathrm{N}$ & 500 & 5 \\
\hline
\end{tabular}

Pearson Correlation was used to testing hypothesis in this research study. The result, the Coefficient of Correlation (r) is 0.828. Based on the decision rule, there is strong positive correlation between work life balance and workplace conflict. The significance level is 0.000 which is below $0.05(\mathrm{p}<0.05)$. Based on the decision rule for significant level, we reject the null hypothesis. Therefore, we conclude that "There is a strong positive relationship between work life balance and workplace conflict.

This means that work place conflict will be decrease when increase the work-life balance of employees. Further research will be discussed about relationship of stress level and satisfaction of employees.

H0: It is hypothesized work-life balance increases, health issues and stress will not decrease

H3: It is hypothesized work-life balance increases, health issues and stress will decrease

Table 8. Hypothesis testing 3

\begin{tabular}{|l|l|l|l|}
\hline \multicolumn{2}{|l|}{} & $\begin{array}{l}\text { I Have enough } \\
\text { time to spend } \\
\text { with } \\
\text { My family }\end{array}$ & $\begin{array}{l}\text { I don't have } \\
\text { chronic illness }\end{array}$ \\
\hline $\begin{array}{l}\text { I Have enough time } \\
\text { to spend with My } \\
\text { family }\end{array}$ & Pearson Correlation & 1 & .776 \\
\cline { 2 - 4 } & Sig. (2-tailed) & & .000 \\
\cline { 2 - 4 } $\begin{array}{l}\text { I don't have chronic } \\
\text { illness work }\end{array}$ & Pearson Correlation & 500 & 500 \\
\cline { 2 - 4 } & Sig. (2-tailed) & .776 & 1 \\
\cline { 2 - 4 } & N & 5000 & 500 \\
\hline
\end{tabular}

Pearson Correlation was used to testing hypothesis in this research study. The result, the Coefficient of Correlation ( $\mathrm{r}$ ) is 0.776 . Based on the decision rule, there is strong positive correlation between work life balance and health issues. The significance level is 0.000 which is below $0.05(\mathrm{p}<0.05)$. Based on the decision rule for significant level, we reject the null hypothesis. Therefore, we conclude that "There is a strong positive relationship between work life balance and health issues.

This means that chronic illness will be decrease when increase the work -life balance of employees. Further research will be discussed about relationship of stress level and satisfaction of employees.

H0: It is hypothesized that Work-life balance and workplace performance will not be significantly related

H4: It is hypothesized that Work-life balance and workplace performance will be significantly related 
DOI: 10.21522/TIJMG.2015.SE.19.01.Art008

ISSN: 2520-310X

Table 9. Hypothesis testing 4

\begin{tabular}{|l|l|l|l|}
\hline \multicolumn{2}{|c|}{} & $\begin{array}{l}\text { I Have enough } \\
\text { time to spend } \\
\text { with My } \\
\text { family }\end{array}$ & $\begin{array}{l}\text { I have rewarded } \\
\text { for my } \\
\text { excellent } \\
\text { performance }\end{array}$ \\
\hline \multirow{2}{*}{$\begin{array}{l}\text { I Have enough time to } \\
\text { spend with } \\
\text { My family }\end{array}$} & Pearson Correlation & 1 & .808 \\
\cline { 2 - 4 } & Sig. (2-tailed) & & .000 \\
\cline { 2 - 4 } $\begin{array}{l}\text { I have rewarded for my } \\
\text { excellent performance }\end{array}$ & $\mathrm{N}$ & 500 & 500 \\
\cline { 2 - 4 } & Pearson Correlation & .808 & 1 \\
\cline { 2 - 4 } & Sig. (2-tailed) & .000 & 500 \\
\hline
\end{tabular}

Pearson Correlation was used to testing hypothesis in this research study. The result, the Coefficient of Correlation ( $\mathrm{r}$ ) is 0.808 . Based on the decision rule, there is strong positive correlation between work life balance and employee performance. The significance level is 0.000 which is below $0.05(\mathrm{p}<0.05)$. Based on the decision rule for significant level, we reject the null hypothesis. Therefore, we conclude that "There is a strong positive relationship between work life balance and performance.

This means that performance will be increase when increase the work-life balance of employees. Further research will be discussed about relationship of stress level and satisfaction of employees.

\section{Discussion}

\section{Introduction}

The research has been conducted based on 16 main industries both private and public sectors. 60\% outcome has been generated on industries of private sector and $40 \%$ on industries in public sector. A majority of female respondents have taken part in the survey compared to male respondents. The generated results indicate that 70 employees are personally committed due to one or more dependents of the family. $86 \%$ employees have gained more than 1-year experience in their existing company. However, it demonstrates that many employees have a considerable relationship with their organizations.

Although a majority of the employed are satisfied with their jobs, few reports being satisfied with particulars such as opportunities for progression, flexibility, and employee recognition.

Nearly two-thirds $(60 \%)$ of the employed category work more than 45 hours a week and less than half (44\%) are compelled to work on overtime basis in order to complete their work. Further, nearly two third $(62 \%)$ among the employed state that they are satisfied with their job and few (13 percent) is not happy with their job role.

However, more than two thirds of (79 \%) being satisfied with the social recognition practices of their employer and only one third ( $35 \%$ ) report feeling their employer providing sufficient opportunities for selfprogression.

Whilst half $(50 \%)$ of the employed population are able to finish their tasks during working hours $28 \%$ are incapable in managing their work load during office hours. $25 \%$ of the employed have not specifically responded to this question.

While one third of the employed population enjoy their leisure with families another one third of same population agonies due to the time lacked being with their families. More than one third (35 percent) of workers detailed that they typically feel tensed or stressed during their day at work and another one third $(32 \%)$ does not entertain their personal life due to work the workload. Almost half (49\%) informed that low salary and work load significantly impact their stress level at work.

Employees also cite that deficiency of opportunities for growth and improvement rate as (43\%), employees involved in heavy workload as (43\%), those with unrealistic job expectations (40\%) and those occupied in long hours as (39\%) as significant sources of stress. 
Less than half of the employees (32\%) declared that they receive non-monetary rewards and recognition for their contributions at work and only $57 \%$ reported being satisfied with their employer's work-life balance practices.

Merely $52 \%$ of employees stated that they feel valued when working, only two thirds reported being motivated to do their best at work and almost a third (32\%) indicated that they intend to seek employment elsewhere within the next year.

Findings show negative correlation between stress level, working hour and overtime. When it comes to work during vacation, it shows positive correlation with stress. Some findings indicate positive correlation between work load and stress level furthermore responsibilities are also positively correlated to the level of stress. Family commitments and also Leisure create positive correlation with the level of stress.

The findings show that there are positive correlations with health issues and workload, not only does it indicate positive correlation between workload and family conflicts further family conflict is positively correlated with overtime and holiday work.

Performance is positively correlated with work load as well as regular working time. There are positive correlations between work load and health issues and there are positive correlations between work load and family conflicts. There is also positive correlation between overtime, working on Poya day and family conflicts. There are positive correlations between performance and work load. Further to it, positive correlation could be viewed between regular working hours and performance and there are negative correlations between working hours, working overtime and level of stress of the employees, but there will be a positive correlation between Poya day working and stress.

\section{Conclusion and Recommendation}

\section{Conclusion}

This study concludes that work life balance philosophy is associated with real benefits for an organization due to the mere fact that social and psychological life of every employee needs to be rightly put in check for them to be an asset and not just an employee who is used to carry out day to day operations of the organization.

Based on the findings of this study, it can therefore be concluded that government sector industries are practicing work life balance but many privet sector industries are still believing hard work and performance other than the work life balance and performance. But privet sector still survives due to other facilities which they offer to the employees other than the government sector. This implies that work life flexibility practices give employees prerogative to adjust when, where and how they work in order to balance work and non-work demands such as taking leaves to pursue career, for care giving and other personal reasons.

Based on the results of this study, it can be concluded that consideration of family responsibilities aspects that pertains to employees, can greatly influence performance in both privet and government sector employees in Sri Lanka. Child care issues, dependent care and employees having balanced time with the family had a positive and significant linear relationship on the measures of performance which were customer satisfaction, target standards, employee satisfaction. The multiple regression results of this study indicated that there is linear relationship

Between family responsibilities and performance. This would imply a spillover effect to the organization in terms of customer satisfaction, meeting targets and standards and ensuring employee satisfaction hence increased overall performance to the organization and vice versa.

\section{References}

[1]. Azeem, S.A, \& Akhtar, N. (2014). The influence of work life balance and job satisfaction on organizational commitment of healthcare employees. International journal of Human Resource Studies, 4(2), 18-24.

[2]. Bailyn, Lotte; Drago, Robert; and Kochan, Thomas A.; "Integrating Work and Family Life - A Holistic Approach”. A Report of the Sloan Work-Family Policy Network. 9/14/2001: pp 1- 10. 
DOI: 10.21522/TIJMG.2015.SE.19.01.Art008

ISSN: 2520-310X

[3]. Eikhof, R., Warhurst, C., \& Haunschild, A. (2007). Introduction: What work? What life? What balance? Employee relation, 29 (4), 325-333. http://dx.doi.org/ 10.1108/ 01425450710839452.

[4]. Factors affect productivity. (2012). Retrieved from http://www.nbrii.com/employeesurvey- white-papers/5factors-that-affect-your-employees-productivity.

[5]. Hudson Resourcing. (2005) The case for work/life balance: Closing the gap between policy and practice. Hudson Australia and New Zealand available on www.hudson.com.

[6]. Jeffrey H. Greenhaus, Karen M. Collins \& Jason D. Shaw, "The relation between work-family balance and quality of life", Journal of Vocational Behavior 63 (2003) 510-531.

[7]. Marks,S, \&MacDermid, S. (1996). Multiple Roles and the Self: Atheory of Role Balance.

[8]. Pleck, J H (1977). “The Work-Family Role System,” Social Problems, 24(4), 417-427.

[9]. Walter, J. \& Walters, J. (2010). Positive management: Increasing employee productivity. New York, USA: Business Expert Press, LLC.

[10]. Wang, Y., \& Zhang, J. (2017). Relationship between work- family balance and job satisfaction Among employees in China: a moderated mediation model. Psych journal, 6(3), 194-204. http://dx.doi.org/10.1002/pchj.174. [11]. Women of tomorrow: A study of women around the world, Nielsen Women of Tomorrow Study 2011, Nielsen Company.

[12]. Ziegler, R., Hagen, B., \& Diehl, M. (2012). Relationship between job satisfaction and Job performance: Job ambivalence as a moderator. Journal of applied social Psychology, 42(8), 2019-2040. http://dx.doi.org/10.1111/j.1559-1816.2012.00929. 